\title{
THE EFFECT OF VARIOUS DOSES OF OESTRADIOL $17-\beta$ ON GLYCOGEN DEPOSITION IN THE RAT UTERUS, CERVIX AND VAGINA
}

\author{
A. T. GREGOIRE,* H. RAMSEY AND A. ADAMS \\ Department of Obstetrics and Gynecology, Jefferson Medical College, \\ Philadelphia, Pennsylvania
}

(Received 25th June 1966)

\begin{abstract}
Summary. Administration of oestradiol benzoate, 5 to $200 \mu \mathrm{g}$, intramuscularly daily for 3 days, results in glycogen deposition in the uterus and cervix of castrated Wistar rats. The relation between dose of oestrogen and amount of glycogen deposited is not, however, linear nor did all portions of the tract respond in a similar manner. The glycogen level of the vagina was not affected by the hormone administration, while progesterone lowered the glycogen content of all portions of the tract.

The glycogen metabolism of the mammalian female genital tract is briefly reviewed and discussed.
\end{abstract}

\section{INTRODUGTION}

Glycogen synthesis and deposition in the rat uterus with administration of various doses of oestradiol have been demonstrated (Bo \& Atkinson, 1952; Rosenbaum \& Goolsby, 1957; Boettiger, 1946). The glycogen is localized in the myometrium and only with doses of $10 \mu \mathrm{g}$ was it possible to demonstrate it histochemically in the endometrium. The enzyme kinetics of glycogen synthesis in the rat uterus is a first order reaction rate (Bitman, Cecil, Mench \& Wrenn, $1965)$ with maximal synthesis occurring with $1 \mu \mathrm{g}$ of subcutaneously administered oestradiol.

In the mouse female genital tract, glycogen content differs both during the oestrous cycle and within portions of the tract. Uterine glycogen levels are maximal at pro-oestrus and oestrus while vaginal glycogen is maximal at metoestrus and minimal at oestrus (Balmain, Biggers \& Claringbold, 1956).

In the investigations of oestrogen-induced genital tract glycogen synthesis performed so far, one or two levels of oestrogen have been used and the investigation has been restricted to a single portion of the tract. The possible interrelationships of genital tract glycogen deposition with increasing doses of oestradiol and in all portions of the tract has not been evaluated.

\section{MATERIALS AND METHODS}

A total of 110 female Wistar rats, weighing 150 to $200 \mathrm{~g}$, were used. The animals were spayed and rested for at least 7 days before being randomly assigned

\footnotetext{
* Present address: Center for Research in Reproductive Biology, Department of Obstetrics and Gynecology, University of Michigan, Ann Arbor, Michigan.
} 
to an experimental group. The animals in each experimental group received either $0,5,25,50,100$ and $200 \mu \mathrm{g}$ of oestradiol benzoate or $1 \mathrm{mg}$ of progesterone intramuscularly for 3 days. On the 4 th day, the animals were killed, the genital tract rapidly removed, separated, weighed, placed in a solution of $30 \%$ $\mathrm{KOH}$ and digested for $20 \mathrm{~min}$. Glycogen was determined by the anthrone method (Seifter, Dayton, Novic \& Muntwyler, 1950) and results expressed as $\mu \mathrm{g}$ of glycogen $/ 100 \mathrm{mg}$ wet weight of tissue.

\section{RESULTS}

The glycogen levels of the genital tract are listed in Table 1. In the spayed animal, the uterine and vaginal glycogen levels were of similar magnitude, while cervical tissue contained about one-half of the amount.

A standard analysis of variance demonstrated significant differences in

TABLE 1

AVERAGE $\mu \mathrm{g}$ OF GLYCOGEN/100 mg AND S.E. OF (WET WEIGHT) TISSUE FROM THE FEMALE RAT GENITAL TRACT OF SPAYED RATS RECEIVING INCREASING DOSES OF OESTROGEN OR $1.0 \mathrm{mg}$ OF PROGESTERONE

\begin{tabular}{|c|c|c|c|c|c|c|c|}
\hline & \multicolumn{7}{|c|}{ Treatment } \\
\hline & \multicolumn{6}{|c|}{ Oestrogen ( $\mu \mathrm{g}$ of oestradiol benzoate) } & \multirow{2}{*}{ Progesterone } \\
\hline & 0 & 5 & 25 & 50 & 100 & 200 & \\
\hline $\begin{array}{l}\text { No. of } \\
\text { animals }\end{array}$ & 10 & 10 & 20 & 20 & 20 & 20 & 10 \\
\hline $\begin{array}{l}\text { Uterus } \\
\text { Cervix } \\
\text { Vagina }\end{array}$ & $\begin{array}{l}56 \cdot 3 \pm 10 \\
30 \cdot 8 \pm 3 \\
61 \cdot 0 \pm 9\end{array}$ & $\begin{array}{l}57 \cdot 8 \pm 5 \\
67 \cdot 7 \pm 12 \\
50 \cdot 3 \pm 7\end{array}$ & $\begin{array}{c}154 \cdot 8 \pm 15 \\
96 \cdot 0 \pm 15 \\
58 \cdot 6 \pm 5\end{array}$ & $\begin{array}{c}146 \cdot 3 \pm 13 \\
61 \cdot 0 \pm 6 \\
56 \cdot 9 \pm 7\end{array}$ & $\begin{array}{c}123 \cdot 6 \pm 11 \\
65 \cdot 4 \pm 9 \\
43 \cdot 4 \pm 5\end{array}$ & $\begin{array}{c}129 \cdot 7 \pm 10 \\
75 \cdot 4 \pm 12 \\
44 \cdot 2 \pm 8\end{array}$ & $\begin{array}{l}35 \cdot 8 \pm 5 \\
21 \cdot 5 \pm 4 \\
40 \cdot 8 \pm 5\end{array}$ \\
\hline
\end{tabular}

amounts of uterine glycogen with all doses of oestradiol greater than $5 \mu \mathrm{g}$. No statistical differences between the spayed and $5 \mu \mathrm{g}$ level were observed when Duncan's Multiple Range Test (Harter, 1960) was applied to make all possible comparisons with all oestrogen levels. Oestradiol dosages above $5 \mu \mathrm{g}$ increased the levels of uterine glycogen significantly $(P<0 \cdot 01)$, but not in a linear fashion. The average glycogen levels of the oestrogen groups above the $25 \mu \mathrm{g}$ dose were lower, but not significantly so.

The cervical glycogen was significantly increased above the spayed level $(P<0.05)$ with administration of oestradiol. Maximum deposition was observed with $25 \mu \mathrm{g}$ dose and no further increases with higher doses of oestradiol occurred. No significant changes in vaginal tissue glycogen were demonstrated in oestrogenadministered animals, as compared with controls.

The administration of $1 \mathrm{mg}$ of progesterone had a glycogenolytic effect and decreased the glycogen content to below spayed levels in all portions of the tract, though in no case was the difference significant $(P=0 \cdot 1)$. 


\section{DISCUSSION}

The results demonstrate that the female rat genital tract tissue does not respond to increasing levels of oestrogen with subsequent increases in glycogen deposition in all tissues. Uterine glycogen synthesis is maximal at the $25 \mu \mathrm{g}$ dose and increasing oestrogen levels did not result in increased glycogen deposition. Other workers have demonstrated maximal deposition $24 \mathrm{hr}$ after administration of a single dose of $1 \mu \mathrm{g}$ of subcutaneously administered oestradiol with subsequent decreases in synthesis $48 \mathrm{hr}$ later (Bitman et al., 1965). These differences in amounts of oestrogen for maximum synthesis may be due to the methods used, i.e. 3 days' oestrogen therapy rather than a single dose, and intramuscular as opposed to subcutaneous administration.

The cervical tissue reaction was intermediate between those of the uterus and vagina. With the exception of the spayed and $5 \mu \mathrm{g}$ levels, the glycogen levels were all greater than vaginal levels, but less than uterine. A similar reaction has been observed with the epithelial structure of the rat cervix during various phases of the oestrous cycle (Hamilton, 1947).

The synthesis of mammalian genital tract glycogen either during the reproductive cycle or with administered hormones exhibits great species differences. In the primate, whose reproductive cycles are of relatively long duration, the uterine glycogen is maximal at the secretory phase (VanDyke \& Ch'en, 1936; Zondek \& Stein, 1940) but, in the rodent, with short, frequent cycles, the uterine glycogen synthesis is dependent on oestradiol (Bo \& Atkinson, 1952; Rosenbaum \& Goolsby, 1957).

Information on cervical glycogen content in the experimental animal is lacking. In the human, cervical glycogen has been described as either minimal or absent (Simon, 1934; Atkinson, Shettles \& Engle, 1948) and cervical mucus glycogen is lowest at the time of ovulation (Pommerenke, 1946; Breckenridge \& Pommerenke, 1951).

The primate vaginal glycogen varies with the cycle (Corner, 1923) and anatomical location (Rakoff, Feo \& Goldstein, 1944). Early workers, using histochemical methods, could not demonstrate glycogen in the vaginal tissue of the pig, lamb, squirrel (Bremicker, 1927), cat, rat, dog, rabbit, guineapig or cow (Cruickshank \& Sharman, 1934). Mouse vaginal glycogen deposition, however, is cyclic, not maximal at the period of mitotic activity but at the period of cornification. The greatest amounts are in the region immediately under keratin formation-the stratum spinosum (Balmain et al., 1956) suggesting a possible role in keratin formation.

The polymers of glucose, maltotetraose, maltotriose, maltose, as well as glucose, products of enzymatic breakdown of glycogen (Torres \& Olavarria, 1961), have been isolated in human vaginal fluid and epithelium (Sumawong, Gregoire, Johnson \& Rakoff, 1962; Gregoire, 1963). These oligosaccharides are also present in the entire rabbit genital tract (Gregoire \& Gibbon, 1965) where they were increased with oestrogen and decreased with progesterone administration. The presence of these compounds suggests that glycogen may be hydrolysed to simpler products and utilized as energy source for activity of the reproductive tract or utilization by the gametes. 


\section{ACKNOWLEDGMENTS}

The authors are grateful to $\mathrm{Dr} \mathrm{H}$. Menduke for assistance in the statistical analysis, also to the Ford Foundation for a stipend (H.R.).

This investigation was supported by the senior author's Research Grant No. HD 01402-01 from the National Institutes of Health, Public Health Service.

\section{REFERENCES}

Atrunson, W. B., Shetrues, L. B. \& Engle, E. T. (1948) Histochemical studies on the secretion of mucus by the human endocervix. Am. 7. Obstet. Gynec. 56, 712.

Balmain, J. H., Biggers, J. D. \& Claringbold, P. J. (1956) Glycogen, wet weight and dry weight changes in the vagina of the mouse. Aust. F. biol. Sci. 9, 147.

Bitman, J. H., Cecil, H. C., Mench, M. L. \& Wrenn, T. (1965) Kinetics of in vivo glycogen synthesis in the estrogen-stimulated rat uterus. Endocrinology, 76, 63.

Bo, W. J. \& Atrinson, W. B. (1952) Histochemical studies on glycogen deposition in the uterus of the rat. I. In intact cyclic animals and in castrates treated with ovarian hormones. Anat. Rec. 113, 91.

Boettiger, E. G. (1946) Changes in the glycogen and water content of the rat uterus. F. cell. comp. Physiol. 27, 9.

Bregkenridge, M. A. \& Pommerenke, W. T. (1951) Analysis of carbohydrates in human cervical mucus. Fert. Steril. 2, 29.

Bremicker, W. (1927) Vergleichende studien über die Biologie der Vagina. Arch. Gynaek. 129, 807.

Corner, G. W. (1923) Ovulation and menstruation in Macacus rhesus. Contr. Embryol. 15, 73.

Cruickshank, R. \& Sharman, A. (1934) The biology of the vagina in the human subject. 7. Obstet. Gynaec. Brit. Emp. 41, 190.

GREGoIRE, A. T. (1963) Carbohydrates of human vaginal tissue. Nature, Lond. 198, 996.

GREGoIRE, A. T. \& GrBbon, R. (1965) Glucosyl oligosaccharides of the rabbit genital tract: Effects of ovarian hormone administration. Int. F. Fert. 10, 151.

Hamicton, C. E. (1947) The cervix uteri of the rat. Anat. Rec. 97, 47.

HARTer, H. L. (1960) Critical values for Duncan's new multiple range test. Biometrics, 16, 671.

Pommerenke, W. T. (1946) Cyclic changes in the physical and chemical properties of cervical mucus. Am. 7. Obstet. Gynec. 52, 1023.

Rakoff, A. E., Feo, L. G. \& Goldstein, L. (1944) The biologic characteristics of the normal vagina. Am. 7. Obstet. Gynec. 47, 467.

Rosenbaum, R. M. \& Goolsby, C. M. (1957) The histochemical demonstration of hormonally controlled, intracellular glycogen in the endometrium of the rat. F. Histochem. Cytochem. 5, 33.

Setfter, S., Dayton, S., Novic, B. \& Muntwyler, E. (1950) The estimation of glycogen with the anthrone reagent. Archs Biochem. 25, 191.

Srmon, H. J. (1934) Glycogen production in the isthmus uteri. Am. F. Obstet. Gynec. 27, 284.

Sumawong, V., Gregoire, A. T., Johnson, W. D. \& Rakoff, A. E. (1962) Identification of carbohydrates in vaginal fluid of normal females. Fert. Steril. 13, 270.

Torres, H. N. \& Olavarria, J. M. (1961) Metabolism of maltooligosaccharides. Acta physiol. latinoam. $11,95$.

VANDyke, H. B. \& Ch'EN, G. (1936) Observations on the biochemistry of the genital tract of the female macaque particularly during the menstrual cycle. Am. F. Anat. 58, 473.

Zondek, B. \& Stein, L. (1940) Glycogen content of the human uterine mucosa glycopenia uteri. Endocrinology, 27, 395. 